\title{
Intercultural Language Competence and Business Communication
}

\author{
Valentina Golysheva \\ NARFU (Northern Arctic Federal University, Archangel, Russia)
}

\begin{abstract}
Teaching modern languages for specific purposes requires the investigation of the interaction of language and socio-cultural aspects, the knowledge of which predetermines successful acquisition of intercultural competence by the students.

Students studying business language should be recommended to do the research in the theory of language planning namely Political Correctness (PC).

Observing politeness strategy, i.e. avoiding direct imposition either in conditional requests or imperatives might be useful for students studying English to be learned as value one. To reduce the level of imposition most English officials prefer to stick to the strategy of disguised imperatives, i.e. rephrase their public messages by employing specific periphrastic expressions in a statement/request/notice/announcement.

In the teaching process priorities should be given to introducing the situational language, the speech etiquette in the English and Russian communities; teaching students to assess social responses.
\end{abstract}

Key words: intercultural competence, politeness strategy, situational language, speech etiquette, periphrasis, political correctness.

\section{Introduction}

The life style of any community is shaped by the way people use their language and people in various cultures use languages differently. So one of the challenging issues for Russian students within an English context is investigating disparities in language use. Meanwhile students should bear in mind that these disparities are culturally determined.

The disparities that are concealed in the Russian and English speaking cultures maybe damaging for intercultural business communication and that explains why students should be motivated to thoroughly analyze and study these disparities in language use and in cultures/mentalities. This might be helpful to them in a more successful acquisition of intercultural competence skills.

\section{Politeness Strategy}

To avoid any misunderstanding in intercultural relationships, Russian students should primarily be given an explicit statement of English values and ethos. One of the most distinct features of the English culture is the ability of the people to observe politeness strategy. Karen Hewitt, professor from Oxford University in her book "Understanding Britain" which is specially written for the Russian reader gives a few generalizations about the British and their social priorities. Thus Hewitt observes: "Foreign students learn that you must not use a simple imperative when you are in England. "Sit down" 
sounds very rude, because it is an order. And we resist orders just as we resist trying to order other people to do things. So I might say, "Would you like to sit down?" The sentence is shaped to allow the other person to say, "Thank you, but I don't want to sit down". In other words, an Englishman, at a subconscious level is always taking into account the fact that the other person may not wish to do what I suggest and that person should be offered a polite way to refuse my proposal" (Hewitt 2009:208).

Why do the English use language in this way? The answer is because the English are trained from an early age to judge and assess social responses" (Hewitt 2009:209). For instance, when discussing their employment with somebody the English try to avoid the direct question of payment: "Is your sister well-paid? How is it from the money point of view? In the same situation the Russian person will ask directly: "How much does your sister earn? What is her salary?" asking the details of payment is a taboo in UK. People in the English speaking communities tend to encourage tact, sympathy and respect in reference to other people. T. Scarrot comments on politeness strategy in the English social behavior: "In to-day's mad world, politeness is more important than ever.... being polite and considerate should be a top priority" (Scarrot 2000:49). Social priorities in the English speaking communities are clearly reflected in their language (see Jones 1989; Blundell 1992). Due to the functional approach to the language there appeared a great number of works on the theory of linguistic/speech politeness. The numerous authors of this theory have successfully developed a typology of speech acts - their cognitive status, cultural dependence and speech norms (see the review of papers by Gabrielle Kasper, 1990, 2001) It's becoming an axiom, that "any language reflects the culture and mentality and it is vividly seen in the speech etiquette" (Wierzbicka 1990).

Situational language/speech etiquette - It's indisputable that the task of a teacher of a foreign language is to examine the extent to which language communities differ in their application of politeness principle (PP) Priorities should be given by introducing the situational language in the teaching process. It might be of interest to show in this paper several situations which demonstrate extreme diversity of the speech etiquette in the English and Russian communities:

In a shop:

Shop assistant: Can I help you Madam/Miss?;

Russian speaker: Hem, спасибо! No, thanks!

English speaker: Oh, thank you very much. I'll just have a look around on my own. Maybe later?

The response of the Russian customer sounds too abrupt and somewhat negative, lacking the assessment of the positive social response of the saleswoman.

At the classes:

- Teacher: Thank you for coming to my classes.

Russian student: You are welcome! 
- Teacher: Our class is over. Have a nice day!

English student: Thanks! You too.

Russian student: No response, simply leaving the classroom.

Politeness Strategy in the British culture might as well be useful for Russian students of English to be learned as value one perhaps. One of the striking features of the English social behavior from the point of view of verbal politeness is the ability to avoid direct imposition either in conditional requests or imperatives. People in the English-speaking cultures are very sophisticated in expressing requests in the most polite way.

At the library:

The English reader: Could I possibly have this book for a couple of days? I need it awfully.

The Russian reader: Bы не можете дать мне эту книгу на два дня? (Can't you give me this book for two days?)

The phrase "can't you give me the book" sounds to the English librarian somewhat impolite and even aggressive because of the negation in it (which is a norm for the Russian language).

It is quite important for the Russian students of English to realize that lack of politeness strategy in the speech of an interlocutor may be associated with aggressiveness by the members of the English-speaking community.

Imperatives in requests - Unlike Russian community people in the UK tend to avoid the direct imposition in their speech. For instance, English mothers always find a good excuse to make their kid help her about the house: "Please, could you just wash it up? I am so tired". So the request sounds less imperative. In the Russian families the kid is not requested to do something but usually gets an imperative command: "Ann, go and wash up the dishes at once”.

English wives often apply to disguised imperatives when they want to make their husbands do something for them. Thus, the phrase "David, would you like to have a cup of tea?" actually contains an implicit order (imposition) for her husband to go into the kitchen and put the kettle on. When an English wife doesn't like the idea that her husband is going to water the flowers in the garden in the heat she might say in a very evasive way "You don't want to water the flowers now, darling, do you?". The Russians will most probably use the negative imperative "You don't have to water the flowers now" or more direct "Don't water the flowers now!; Stop watering the flowers now!".

Public imperatives-implicit imposition - In fact, most officials in English community prefer to stick to the strategy of disguised imperatives. They permanently rephrase messages in public imperatives by employing specific periphrastic expressions that soften what they want to emphasise and make it sound less direct. There's a lot of psychology about it when people don't want to be told what to do or what to refrain from 
doing. In other words, the application of disguised imperatives in a statement /request/notice/announcement reduces the level of imposition. It makes the implicit imposition (contained within the semantic structure of the message) sound milder, vague, less blunt or disagreeable.

The strategy of disguised imperatives is extremely popular in notices and announcements used by English and Swedish communities for most public places like cafes, restaurants, movies, museums, gyms, pubs, etc. They usually illustrate an amazing variety of the verbal expression carrying implicit imposition. Compare the variants:

Собаки запрещень!! Dogs are prohibited! (Russian)

In the interest of hygiene No Dogs! (English)

He кypumb! No Smoking! (Russian)

This is a no-smoking area. Thank you for your understanding. (English)

We are a no smoking school. Your cooperation is appreciated. (English)

So one of the challenging issues for teachers of modern languages is to examine the extent to which cultural communities differ in their verbal business communication. Students studying business language should be recommended to do the research in the theory of language planning (see Christian 1993) - the so-called Political Correctness (PC - see in Cameron 1995) which might positively affect the acquisition by them of intercultural competence and contribute to a better cross-cultural relationship.

\section{References:}

1. Blundell, J.; Higgens, J.; Middlemiss, N. (1992) Function in English. Oxford: OUP.

2. Cameron, D. (1995) Verbal Hygiene. London: Routledge.

3. Christian, D. (1993) Language Planning: the View from Linguistics. // Linguistics; the Cambridge Survey IV. Cambridge.

4. Hewitt, K. (2009) Understanding Britain. Perspective Publications. Ltd.

5. Jones, L.; von Baeyer, C. (1989) Functions of American English. / Communication Activities for the Classroom. Student's book. Cambridge: CUP.

6. Kasper, G. (1990) Linguistic Politeness. // Journal of Pragmatics. N14. North Holland.

7. Kasper, G. (2001) "Politeness" in Rajend Mesthrie (ed) Concise Encyclopedia of Sociolinguistics. Oxford: Elsevier.

8. Scarrot, T. (2000) Don't be Silly, be Polite. // Yorkshire Riding Magazine. June/July.

9. Wierzbicka, A. (1990) Cross-Cultural Pragmatics. Berlin: Mouton de Gruyer. 


\section{Lthquứzulnıpujpfi ppuqtilnıpjnıfin phqfiku hunnpnulgnnıpnntinıu}

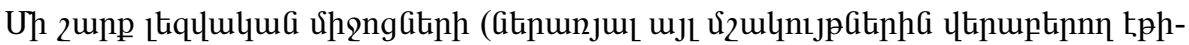

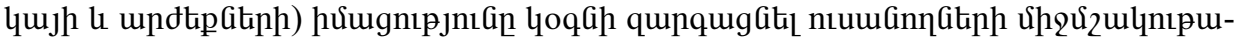

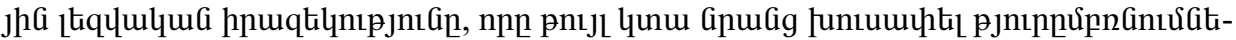

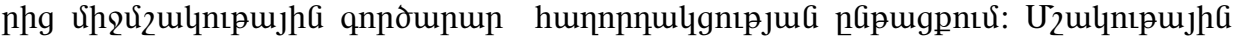

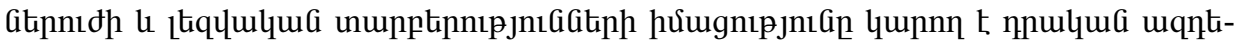

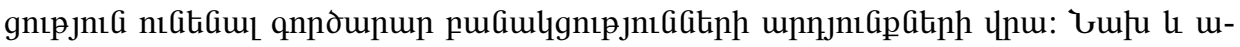

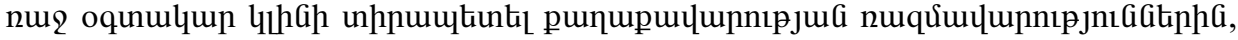

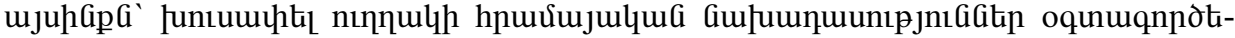

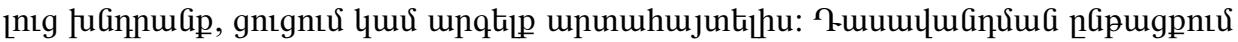

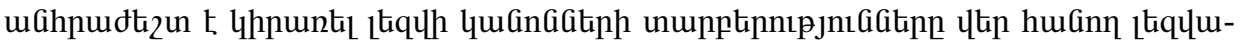

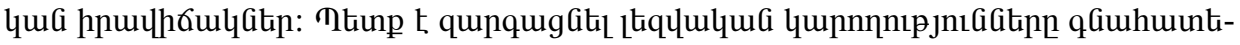

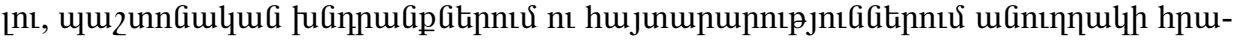

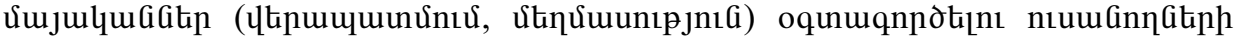
hưunnıpjnıGGitinn:

\section{Языковые компетенции в межкультурной бизнес коммуникации}

Для более успешного приобретения межкультурных языковых компетенций студенты должны овладеть набором языковых инструментов, касающихся этики и ценностной ориентации другой культуры. что позволит им избежать непонимания в межкультурной бизнес коммуникации. Знание разницы культурного потенциала и языковых различий может наилучшим образом повлиять на результаты бизнес переговоров. В первую очередь, полезно овладеть стратегией вежливости, т.е. избегать прямого императива в просьбах, указаниях и запретах. При обучении необходимо разыгрывать языковые ситуации, иллюстрирующие различия в языковом этикете. Следует развивать у студентов навыки оценки языковых компетенций; овладение скрытым императивом, т.е. употребление перифраз и эвфемизмов в официальных просьбах, заявлениях и обьявлениях. 